\title{
MEMOIR
}

\section{SIR HERBERT TETLEY}

Sir Herbert Tetley died on 12 March 1999 at the age of 90 . He was born in Leeds on 23 April 1908, and was educated at Leeds Grammar School before reading mathematics at The Queen's College, Oxford.

He joined the London Life Association in 1930, after graduating with a double first, and qualified as FIA in 1934. He spent two years with the Scottish Provident Institution and then joined the National Provident Institution in 1938, where he remained for 13 years, rising to become Joint Actuary. In 1951 he took up the post of Principal Actuary at the Government Actuary's Department (GAD), was promoted to Deputy Government Actuary in 1953 and appointed Government Actuary on 1 April 1958, on the retirement of Sir George Maddex. Tetley was the fifth person to hold the post of Government Actuary, remaining in post for 15 years until his retirement on 30 April 1973.

His time as Government Actuary saw major changes in the life insurance and pensions fields, including the introduction of graduated pensions in 1961 and the attempts of successive Governments to reform the State social security arrangements in the late 1960s and early 1970s, notably the Crossman scheme and the Keith Joseph scheme.

He was a man of charming disposition, who enjoyed excellent relationships with other senior civil servants and with Ministers, and ran the department with firmness combined with a ready willingness to delegate and to leave his divisional heads with the freedom to run their parts of the business.

He was co-opted to the Institute Council in October 1946, on the death of Sir Percy Harvey, the third Government Actuary, although this was several years before a career move took him to the GAD. He was subsequently elected to Council three times, in 1947, 1956 and 1962, serving a total of almost 23 years on Council. He served as Chairman of the Board of Examiners from 1950 to 1953 , Honorary Secretary from 1953 to 1955, Vice-President from 1957 to 1960 and President from 1964 to 1966.

Sir Herbert was also active in the Royal Statistical Society, serving as its Vice President from 1961 to 1962 . He was the author of two statistics text books for the actuarial profession. The first, Actuarial Statistics, Volume I (Statistics and Graduation), was published in 1946 (second edition in 1950). The second, Statistics: An Intermediate Text-Book, was written jointly with Dr Norman L. Johnson and was published in two volumes, the first appearing in 1949 (second edition 1962) and the second in 1950. This text was retained on the syllabus for the examinations of the Institute until 1968 and for the Faculty of Actuaries until 1974.

He was made a Companion of the Order of the Bath (CB) in 1958 and knighted (KBE) in 1965. He held appointments on several public commissions, including the Committee on Economics of the Road Research Board (1962-65) and the Committee on Road Traffic Research (1966-73), and was Chairman of the Civil Service Insurance Society and the Civil Service Annuities and Assurance Society (a registered friendly society) from 1961 to 1973 . He was also active in the masonic movement, and for some years held the post of Grand Treasurer, as well as being Chairman of the Governing Body of the Royal Masonic Institution for Boys. On a lighter note, he was an enthusiast for Scottish dancing and enjoyed singing, being at one time a member of the Bach choir.

He is survived by his widow Agnes (née Macphee), whom he married in 1941, and by his son.

CHRIS DAYKIN 